\title{
CONCOMITANT INFECTION OF HAEMOGREGARINA SP. AND STAPHYLOCOCCUS AUREUS IN FREE-LIVING YELLOW-SPOTTED RIVER TURTLE (PODOCNEMIS UNIFILIS): CASE REPORT
}

(Infecção concomitante de Haemogregarina sp. e Staphylococcus aureus em tracajá (Podocmenis unifilis) de vida livre: relato de caso)

Letícia Pereira Úngari ${ }^{1 *}$, André Luiz Quagliatto Santos², Guilherme Carrara Moreira Paiva ${ }^{2}$, Kelem Cristina Pereira Mota ${ }^{2}$, Lizandra Ferreira de Almeida Borges², Márcia Cristina Cury²

\author{
'Universidade Estadual Paulista "Júlio de Mesquita Filho", Botucatu, SP, Brazil. *Corresponding author: \\ letspungari@hotmail.com \\ ${ }^{2}$ Universidade Federal de Uberlândia, MG, Brazil
}

\begin{abstract}
A male adult yellow-spotted river turtle Podocnemis unifilis (Chordata: Testudines: Podocnemididae) was captured during field collections. Blood sample was collected for haemoparasite screening by conventional light microscopy. Morphometric and morphological analyzes of the parasite developmental stages were performed in the blood extensions, as well as the parasitemia intensity. Gametocytes of hemogregarines and innumerable bacterial cells were observed. To identify the bacteria present, a culture was performed and the presence of Staphylococcus aureus was observed. It was concluded that a co-infection of Staphylococcus aureus (Firmicutes: Bacillales: Staphylococcaceae) and Haemogregarina sp. (Apicomplexa: Adeleina: Haemogregarinidae) was observed in this free-living yellow-spotted river turtle Podocnemis unifilis.
\end{abstract}

Keywords: co-infection; hemogregarines; occurrence; Podocnemis unifilis; Staphylococcus aureus.

RESUMO: Durante coletas de campo, um macho adulto de tracajá Podocnemis unifilis (Chordata: Testudines: Podocnemididae) foi capturado. Amostra de sangue foi colhida para pesquisa de hemoparasitos pela microscopia óptica convencional. Nas extensões sanguíneas foram realizadas análises morfométricas e morfológicas das formas evolutivas encontradas, bem como o cálculo da parasitemia. Foram observados gametócitos de hemogregarinas e inúmeras células bacterianas. Para identificação das bactérias presentes foi realizada cultura, sendo observada a presença de Staphylococcus aureus. Conclui-se que havia co-infecção por Staphylococcus aureus (Firmicutes: Bacillales: Staphylococcaceae) e Haemogregarina sp. (Apicomplexa: Adeleina: Haemogregarinidae) no tracajá Podocnemis unifilis.

Palavras-chave: co-infecção; hemogregarinas; ocorrência; Podocnemis unifilis; Staphylococcus aureus. 


\section{INTRODUCTION}

The yellow-spotted river turtle Podocnemis unifilis Troschel 1848, is a semi-aquatic turtle widely distributed in South America (Arraes and TavaresDias, 2014). In the literature, there are few reports of pathogens affecting these turtle species, being the hemogregarines hemoparasites commonly reported (Soares et al. 2014; Espinoza et al. 2017).

The hemogregarine parasites (Apicomplexa: Adeleina) are characterized as an intracellular protozoan with heteroxenic lifecycle and frequently found in reptiles (Telford, 2009; Soares et al., 2014). The genus Haemogregarina (Apicomplexa: Adeleina: Haemogregarinidae) is common in aquatic turtles and has been documented in several countries (Telford, 2009) However in Brazil, there are only a few reports (Soares et al., 2014; Picelli et al., 2015; Úngari et al., 2018). A recent study from Úngari et al. (2018) characterized through morphological, morphometric and molecular analyses, a new species Haemogregarina podocnemis in Podocnemis unifilis, being the first Haemogregarina species described in a Brazilian turtle.

Another pathogen observed in reptiles, including turtles, although less common, is the bacteria Staphylococcus aureus (Firmicutes: Bacillales: Staphylococcaceae). It is present in a wide variety of animal species, including mammals, birds, and reptiles, and may be commensal or pathogenic (Santoro et al., 2006). S. aureus pathogenesis and, consequently, the host clinical condition are associated with several factors, immunity for example.

Studies in captive sea turtles have demonstrated the association of $S$. aureus with bronchopneumonia, obstructive rhinitis, traumatic ulcer, and ulcerative stomatitis (Glazebrook and
Campbell, 1990; Orós et al., 2005). Nonetheless, there are no studies associating Staphylococcus aureus with parasitic diseases.

Therefore, the aim of this study was to identify the hemogregarines (Apicomplexa: Adeleina) affecting aquatic turtles in their natural habitat, unexpectedly, a concomitant infection by Staphylococcus aureus and Haemogregarina sp. was reported.

\section{MATERIALS AND METHODS}

This study was conducted under the approval of the Ethics Committee for Use of Animals of the University of Uberlândia (CEUA-UFU) (protocol 032/16) and the Biodiversity Information and Authorization System (SISBIO) (protocol 51398-1).

In July 2016, a male adult yellowspotted river turtle (Podocnemis unifilis) was captured during field surveys in Red River, Britânia district, Goiás, Brasil (coordinates $14^{\circ} 57^{\prime} 08,4^{\prime \prime}$ South latitude and $51^{\circ} 06 ' 30,7^{\prime \prime}$ West longitude). The specimen was submitted to blood collection with disposable and sterile 3 $\mathrm{mL}$ syringes and needles (22/19), by puncturing the cervical paravertebral venous sinus (Zippel et al., 2001). At the site, three blood smears were performed, and the rest of the material was stored at $-4^{\circ} \mathrm{C}$, in tubes containing EDTA as anticoagulant, for further analyzes at the Laboratory of Serology and Molecular Biology of Parasites of the Federal University of Uberlândia.

The blood smears were fixed with methanol, stained in 10\% Giemsa (Eisen and Schall, 2000) and examined using an optical microscope (Olympus Optical Co) with 40x and 100x magnification.

The hemoparasite parasitemia was estimated according to De Biasi et al. (1989) under 100x magnification. The morphometric analysis of the parasite blood developmental stages was performed by measuring the length, 

yellow-spotted river turtle (Podocnemis unifilis): case report

width, and area of the body and nucleus of the parasites developmental stages.

For the bacteria analysis, an aliquot of the blood sample was sent to the Laboratory of Research in Bacteriology of the Federal University of Uberlândia. To isolate the bacteria, the blood sample was cultured in $1 \mathrm{~mL} B H \mathrm{H}$ (Brain Heart Infusion) broth and incubated at $35 \pm 2^{\circ} \mathrm{C}$, for 24 hours. The culture was then plated on TSA Agar (Trypticase Soy Agar) and Minnitol salt Agar, and the plates were incubated at $35 \pm 2^{\circ} \mathrm{C}$, for 24 hours. Colonies were subjected to Gram staining, catalase test (using $3 \%$ hydrogen peroxide), and coagulase exam (using $0.5 \mathrm{~mL}$ of rabbit plasma). To test antimicrobial susceptibility, a bacterial inoculum was prepared, and antimicrobial disks were placed on the agar surface and incubated at $35^{\circ} \mathrm{C}$ for 16 to 18 hours.

After incubation, the plate was examined under light, and the inhibition halo diameters were compared to the "Clinical and Laboratory Standards Institute ${ }^{\circledR}$ " (CLSI) document to classify as resistant or sensitive (Santoro et al., 2006; Walther et al., 2008; Iverson et al., 2015).

\section{RESULTS AND DISCUSSION}

The occurrence of Haemogregarina sp. in turtles is commonly reported in the literature. Jakes et al. (2001) reported a 100\% occurrence in the long-necked turtle (Chelodina longicollis) and the Brisbane short-necked turtle (Emydura signata), the same way as Mihalca et al. (2002) in the lagoon turtle (Emys orbicularis). In Brazil, a high occurrence of $98 \%$ (Soares et al., 2014) and 100\% (Úngari et al., 2018) were reported for this genus of parasite in free-living $P$. unifilis.

The morphological and morphometric analyses showed gametocytes of different sizes and morphologies. One type of small gametocytes were observed with nuclei not evidenced, similar to a bean shape, with body length, width, and area of the parasite $8.47 \pm 1.58 \mu \mathrm{m}, 4.2 \pm 1.5 \mu \mathrm{m}$, and $15.1 \pm 2.4 \mu \mathrm{m}^{2}$, respectively. No measures of the nuclei were performed, since their nuclei were not delimited. The other type of gametocyte were robust, causing deformations in erythrocytes and displacement of cell nuclei, with nuclei of the parasite delimited; the body length, width, and area of the parasite were, respectively, $17.9 \pm 1.3 \mu \mathrm{m}, 5.4 \pm 0.8 \mu \mathrm{m}$, and $39.1 \pm$ $2.9 \mu \mathrm{m}^{2}$ and the nuclei length, width, and area of the parasite were, respectively, $8.25 \pm 1.30 \mu \mathrm{m}, 3.59 \pm 0.8 \mu \mathrm{m}$, and $13.97 \pm 1.42 \mu \mathrm{m}^{2}$ (Figure 1).

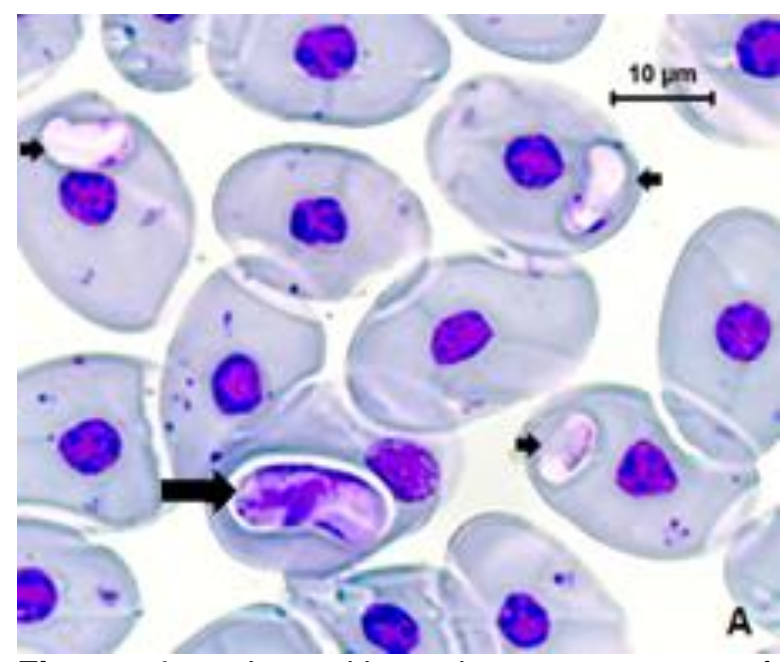

Figure 1 - Intraerithrocytic gametocytes of Haemogregarina sp. (Apicomplexa: Adeleina: Haemogregarinidae) in Podocnemis unilifis. Hemoparasites are indicated by arrows (Small arrows: immature gametocytes; big arrow: mature gametocytes). Scale: $10 \mu \mathrm{m}$.

The same morphologies of gametocytes were observed by Soares et al. (2014) and Picelli et al. (2015) from Brazilian $P$. unifilis and $P$. expansa turtles, respectively. The authors nominated the small gametocytes as microgametocytes and the robust gametocytes as macrogametocytes. The morphometric values were similar too. Therefore, from the morphological and morphometric analyses of the 

hemoparasite blood developmental stages, it was possible to identify Haemogregarina sp. (Apicomplexa: Adeleina: Haemogregarinidae).

Regarding the bacteria, infection with Staphylococcus aureus was confirmed by the detection of protein $A$ by the latex agglutination test (Staphclin). Moreover, the bacterial sample presenting multidrug resistance, including methicillin-resistant Staphylococcus aureus (MRSA), was identified.

Although S. aureus lineages are generally regarded as host-specific, some seem to have several hosts, as they can be isolated from both humans and animals (Hasman et al., 2010). In a study developed by Espinosa-Gongora et al. (2012), the author's analyzed 149 mammals and 21 reptiles kept at the Copenhagen Zoo. S. aureus was detected in 15 individuals, all of which were mammals. None of the isolates presented resistance to methicillin. According to these authors, the negative results obtained for the presence of $S$. aureus in reptiles could indicate that these animals are unlikely natural hosts of this species. However, a study by Walther et al. (2008) reported the presence of MRSA in exotic animals such as bats, parrots, and turtles.

The contact between wild animals and humans has increased progressively due to population growth, consequently, loss of habitat by wild animals. However, this proximity may be a public health problem since the pathogenic potential of some diseases that affect these animals. In this case report, the yellow-spotted river turtle was in its natural environment, which is bordered by a riverine population, whose sewage is released in the river. In addition, this population has a custom (regional culture) to feed on these turtles. The close contact between humans and turtles can provide the ideal transmission route for MRSA strain, being a possible explanation for the turtle infection observed in this case, since there are not many reports on this pathogen in reptiles, especially in their natural environment.

The specimen analyzed herein was co-infected with Haemogregarina sp. and, in the literature, concomitant infections in turtles have been reported usually associated with the quality of the environment in which they live. According to Santoro et al. (2006), the quality of water available to these animals influences the composition of the microbiota, and possible stress conditions can affect the host's immune system, making it more susceptible to infection by these opportunistic bacteria, which are normally present in its microbiota. Among these stress conditions, infection with another parasite should be considered. When an individual is parasitized, the immune system tries to fight the invader, most of the time unsuccessfully, as these hemoparasites have evasion mechanisms. The simple act of the organism fighting against this pathogen causes the host to automatically spend energy. This energy loss influences the behavior of the animal in nature, such as hunting, motility, mating, oviposition, among others (Amo et al., 2004).

\section{CONCLUSION}

From the above information, we can infer that the proximity of humans and wild animals and the frequent environmental contamination imposed by riverine population can directly interferes with the quality of life of wild animals, as well as in their health. In the case reported herein, it is not possible to say which infection led to susceptibility to the other; nevertheless, we can assume that hemogregarine parasite, together with the reduced quality of the river, were crucial for the described situation, since infection with 

yellow-spotted river turtle (Podocnemis unifilis): case report

hemoparasites makes individuals more susceptible to other pathologies.

\section{REFERENCES}

AMO, L.; LOPES, P.; MARTIN, J. Prevalence and intensity of hemogregarinid blood parasites in a population of the lberian rock lizard, Lacerta monticola. Parasitology Research, v.94, p.290-293, 2004.

ARRAES, D. R. S.; TAVARES-DIAS, M. Nesting and neonates of the yellowspotted river turtle (Podocnemis unifilis Podocnemididae) in the Araguari River basin, eastern Amazon, Brazil. Acta Amazonica, v.44, p.387-392, 2014.

DE BIASI, P.; CARDOSO JR, R. B.; SANTOS, S. M. A. Presença de Hepatozoon plimmeri (Sambon, 1909) Coccidia, Haemogregarinidae-em exemplar de Bothrops jararaca (Wied, 1984) - Serpentes, Viperidae, Crotalinae-mantido em cativeiro. Memórias do Instituto Butantã, v.55, p.117-121, 1989.

EISEN, R. J.; SCHALL, J. J. Life history of malaria parasite (Plasmodium mexicanum): independent traits and basis for variation. Proceedings of The Royal Society Biological Sciences, v.267, n.1445, p.793-799, 2000.

ESPINOZA, L. L. et al. A new Myxidium species (Myxozoa: Myxosporea) infecting gall bladder of the turtle Podocnemis unifilis (Testudines: Podocnemididae) from Peruvian Amazon). Acta Tropica, v.172, p.75-79, 2017.

ESPINOSA-GONGORA, C. et al. Occurrence and distribution of Staphylococcus aureus lineages among zoo animals. Veterinary Microbiology, v.158, n.1-2, p.228-231, 2012.
GLAZEBROOK, J. S.; CAMPBELL, R. S. F. A survey of the diseases of marine turtles in northern Australia. I. Farmed turtles. Diseases of Aquatic Organisms, v.9, p.83-95, 1990.

HASMAN, H. et al. Spa type distribution in Staphylococcus aureus originating from pigs, cattle and poultry. Veterinary Microbiology, v.141, p.326-331, 2010.

IVERSON, S. A. et al. Anatomical patterns of colonization of pets with staohylococcal species in homes of people with methiciliin-resistant Staphylococcus aureus (MRSA) skin or soft tissue infection (SSTI). Veterinary Microbiology, v.176, p.202-208, 2015.

JAKES K. A. et al. Hemoprotozoa of fresh turtles in Queensland. The Journal of Wildlife Disease, v.37, p.1219, 2001.

MIHALCA, A. D.; ACHELARIPEI, D.; POPESCU, P. Haemoparasites to the genus Haemogregarina in a population of European pond turtles (Emys orbicularis) from Dragasani, Valcea country, Romenia. Scientia Parasitologica, v.3, p.22-27, 2002.

ORÓS, J. et al. Diseases and causes of mortality among sea turtles stranded in the Canary Islands, Spain (1998-2001). Diseases of Aquatic Organisms, v.63, p.13-24, 2005.

PICELLI, A. M. Prevalence and parasitemia of Haemogregarina sp. in Podocnemis expansa (Testudnes: Podocnemididae) from the Brazilian Amazon. Brazilian Journal of Veterinary Parasitology, v.24, p.191197, 2015.

SANTORO, M. S. et al. Aerobic bacterial flora of nesting green turtles (Chelonia mydas) from Tortuguero Nacional Park, 
Costa Rica. Journal of Zoo and Wildlife Medicine, v.37, n.4, p.549-552, 2006.

SOARES, P. et al. Haemogregarina spp.in a wild population from Porocnemis unifilis Toschel, 1848 in the Brazilian Amazonia. Parasitology Research, v.113, p.4499-4503, 2014.

TELFORD JR., S. R. Hemoparasites of the reptilia: color atlas and text. Boca Raton: CRC Press, 2009. 376p.

ÚNGARI et al. Haemogregarina podocnemis sp. nov.: description of a new species of Haemogregarina Danilewsky 1885 (Adeleina: Haemogregarinaidae) in free-living and captive yellow-spotted river turtles Podocnemis unifilis (Testudines: Podocnemididae) from Brazil. Parasitology Research, v.117, p.1-14, 2018.

WALTHER, B. et al. A Methicillinresistant Staphylococcus aureus (MRSA) isolated from small and exotic animals at a university during routine microbiological examinations. Veterinary Microbiology, v.127, p.171178, 2008.

ZIPPEL, K. C.; LILLYWHITE, H. B.; MLADINICH, C. R. J. New vascular system in reptiles: Anatomy and postural hemodynamics of vertebral venomous lexus in snakes. Journal of Morphology, v.250, p.173-184, 2001. 